Accepted version of article published in Agriculture and Human Values, Final publication is available available at Springer: https://link.springer.com/article/10.1007/s10460-015-9678-8

Full reference: Clapp, Jennifer 2017. "Responsibility to the Rescue: Governing Global Private Financial Investment in Agriculture", Agriculture and Human Values. 34(1), 223-235.

\title{
Responsibility to the rescue?
}

\section{Governing private financial investment in global agriculture}

\section{Jennifer Clapp}

\begin{abstract}
This paper examines the recent rise of initiatives for responsible agricultural investment and provides a preliminary assessment of their likely success in curbing the ecological and social costs associated with the growth in private financial investment in the sector over the past decade. I argue that voluntary responsible investment initiatives for agriculture are likely to face similar weaknesses to those experienced in responsible investment initiatives more generally. These include vague and difficult to enforce guidelines, low participation rates, an uneven business case, and confusion arising from multiple and competing initiatives. In addition, the large diversity of investors and high degree of complexity of financial investments further complicate efforts to discern who bears the burden of responsibility in practice. As a result, there is a strong likelihood that voluntary governance initiatives for responsible agricultural investment will shift discourse more than they will change practice.
\end{abstract}

Keywords: finance, investment, agriculture, food, voluntary initiatives

\section{Author contact information}

Jennifer Clapp (jclapp@uwaterloo.ca)

School of Environment, Resource and Sustainability, University of Waterloo, 200 University Avenue West, Waterloo, ON, N2L 3G1, Canada

\section{Author Biography}

Jennifer Clapp, PhD, is a Canada Research Chair in Global Food Security and Sustainability and Professor in the School of Environment, Resources and Sustainability at the University of Waterloo. She currently holds a Trudeau Fellowship. Her most recent books include Hunger in the Balance: The New Politics of International Food Aid (Cornell University Press, 2012), Food (Polity, 2012), The Global Food Crisis: Governance Challenges and Opportunities (co-edited with Marc Cohen, WLU Press, 2009), and Corporate Power in Global Agrifood Governance (co-edited with Doris Fuchs, MIT Press, 2009).

\section{Acknowledgements}

I would like to thank Graeme Auld, Ryan Isakson, Oane Visser and Noah Zerbe for valuable feedback on earlier drafts. I would also like to thank the Trudeau Foundation and the Social 
Sciences and Humanities Research Council for financial support for this research. Thanks are also due to Rachel McQuail for editorial assistance.

\section{Introduction}

In the past decade, there has been massive growth in private financial investment in agricultural commodity futures contracts, shares in agricultural firms, farmland funds, and commodity index funds. These agricultural investment products enable financial investors to capitalize on gains in food, farm, and farmland assets without taking on the risk of actually owning those assets outright (Fuchs et al. 2013; Fairbairn 2014). The large increase in financial investment in commodity and farmland investments has been highly controversial because of the potential negative externalities associated with these types of investments. On one hand, those promoting these investments point out that private financial resources can provide an important source of much-needed capital for the agricultural sector in developing countries (Hallam 2011). On the other hand, critics have countered that in a number of cases any positive benefits have been outstripped by the costs of this investment, such as more volatile food prices, environmental degradation, and human rights violations (Ghosh 2010; White et al. 2012; McMichael 2010). Although the exercise of weighing the costs and benefits of these investments is highly charged, the potential for negative outcomes associated with these investments is not in question (Deininger and Byerlee 2011; UNCTAD 2011a; World Bank and UNCTAD 2014). What is unclear is how to prevent negative outcomes from occurring, while enabling the positive features of investment in the sector.

In this context, voluntary international governance initiatives aimed at promoting "responsible" private financial investment in agriculture have begun to emerge. In 2010, the World Bank, the Food and Agriculture Organization (FAO), and the United Nations Conference on Trade and Development (UNCTAD) sponsored the Principles for Responsible Agricultural Investment (PRAI). In 2011, a number of investment funds associated with the UN Principles for Responsible Investment (PRI) unveiled the Principles for Responsible Investment in Farmland. Around the same time, the FAO shepherded the adoption of the Voluntary Guidelines on the Responsible Governance of Tenure of Land, Fisheries and Forests in the Context of National Food Security by the Committee on World Food Security (CFS) in 2012. In 2014, the CFS adopted the Principles for Responsible Investment in Agriculture and Food Systems (PRIAFS). 
As newly adopted initiatives, it is too early to provide a full assessment of their performance and impact. Instead, this paper draws on lessons from the literature on voluntary initiatives and responsible finance more broadly and makes a preliminary assessment of their likely ability to rein in the potential social and environmental costs of agricultural investment. I argue that in their current form, the responsible agricultural investment governance efforts are unlikely to bring substantial changes in practice. There are several reasons for this assessment. First, the responsible investment initiatives for agriculture are likely to suffer from the kinds of weaknesses associated with responsible investment initiatives more generally. These include vague and difficult to enforce guidelines, low participation rates, a weak business case, and a confusing array of competing initiatives. Second, financial investment in agriculture brings an added layer of complexity due to the large diversity of investors and financial investment products involved, which obscures the impact of these investments on the ground. This complexity makes it extremely difficult to discern precisely who should be held responsible in practice, which further compounds the existing problems of accountability within voluntary initiatives, and within agricultural systems more broadly. In this highly ambiguous context, voluntary initiatives for responsible agricultural investment are likely to be weak and ineffective.

\section{The changing landscape of food, finance, and farmland}

Financial actors have historically had a close relationship with the food system. Financial speculators have been engaged in commodity futures markets dating back several centuries since

the rise of commodity exchanges in the UK and US (Cronon 1991). In the US, home to the Chicago Mercantile Exchange, the largest agricultural commodity exchange in the world, these markets were tightly regulated for much of the $20^{\text {th }}$ century in a bid to avert excessive financial speculation that could result in market manipulation and price volatility beyond normal levels. These regulations included reporting requirements and position limits (limits on the number of contracts any single trader can hold at one time) on the part of non-commercial (i.e. financial) players involved in these markets (see Berkovitz 2009). Recent decades have seen the intensification of the role of financial actors within the agrifood system, from commodity exchanges, to agrifood value chain functioning, to land markets (Burch and Lawrence 2009; 
Fuchs et al. 2013; Isakson 2014). This “financialization” of the food system, whereby financial actors, financial markets, and financial motives have taken on greater importance in the organization, structure, and trends in food, land, and agricultural relations, has occurred alongside financialization in the broader global economy (see Epstein 2005).

The involvement of financial actors across a range of agricultural value chains intensified following the adoption of neoliberal economic policies in a number of countries in the 1980s. The decades that followed saw progressive deregulation of financial markets, including regulations that governed commodity exchanges and banks. In the US, for example, banks and other financial institutions pressured regulators and won exemptions from position limits in commodity markets in the 1980s and 1990s (Clapp and Helleiner 2012). This relaxation of financial rules governing commodity futures markets was further solidified with the passage of the Commodity Futures Modernization Act of 2000, which exempted over-the-counter trades (that is, trades outside of formal exchanges) from regulatory oversight (Ghosh 2010).

These regulatory changes enabled the development of a new breed of financial investment products linked to food and agriculture, based not just on agricultural commodities, but also on farmland and agrifood company shares. After 2000, there was a sharp rise in investment in what are referred to as commodity index funds (CIFs), which bundle different commodities together and track their prices (IATP 2008). CIFs typically include some combination of agricultural commodity, mineral, and energy futures, with agricultural commodities often making up a third of the index. Other kinds of index funds have also emerged, such as general agricultural index funds that combine and then track prices of agricultural farmland, agricultural input and equipment firm shares, and agricultural commodities (Daniel 2012).

Many governments around the world have also relaxed regulations on foreign direct investment more broadly since the 1980s. This general deregulation in investment regimes took place as part of the broader neoliberal agenda, which advocated a reduced role for state regulation in markets, including for investment. Over the course of the 1990s, approximately 95\% of changes to foreign investment rules resulted in a more favorable environment for foreign investment (UNCTAD 2001). This trend continued in the following decade, although the 2008 financial crisis led to a 
marginal increase in stricter rules, while the overwhelming majority of changes were more liberalizing (UNCTAD 2012). This more open foreign investment regime across a number of countries opened the door for wealthy financial investors to tap into foreign direct investment, including in food, land, and agriculture operations across the globe in ways, and at scales, that were not possible just a few decades earlier when governments took a more active role in setting boundaries on foreign investment.

A range of investors stepped into this new investment space: hedge funds serving large-scale wealthy investors, pension funds managing massive amounts of money, private equity funds investing directly into private companies, mutual funds providing investment vehicles to retail investors, commodity trading firms hedging on their own accord as well as selling investment products for third parties, investment banks selling investment products and hedging their risks, sovereign wealth funds investing on behalf of governments, and insurance companies hedging risks, among others (see McNellis 2009). These investors interact with one another in complex ways-some investing in other investors, some selling products, some buying as investments. Since the early 2000s, agricultural commodity and land investments have risen sharply. Investment in CIFs, which typically include an agricultural component as noted above, grew markedly between 2003 and 2008, increasing from US\$13 billion to US\$317 billion (DeSchutter 2010). Between 2006 and 2011, speculative investment in agricultural commodities almost doubled, from US\$65 billion to \$US126 billion (Worthy 2011). And since 2000, over 900 land deals covering more than 35 million hectares have been concluded, with deals covering some 14 million more hectares still under negotiation (http://landmatrix.org/en/; see also Kugelman and Levenstein 2012).

This increase in food and agriculture investments has been fuelled by two key discourses within financial circles. First, many financial institutions market their products on the premise that agriculture is the "last big industrialization." This discourse posits that the sector will only see increased profit as the demand for commodities increases alongside a rising world population undergoing demographic shifts that result in greater incomes in emerging countries, accompanied by diets higher in grain-rich proteins such as meat and dairy (see HighQuest Partners 2010). Financial institutions offer their customers a chance to capitalize on these 
changes. Second, investment funds market land and agricultural commodity investments on the grounds that they act as a good hedge against inflation because their performance is not correlated to other more traditional asset classes such as equities and bonds. As money has flowed into this sector, a complex set of trends has emerged where energy, food, and land markets are increasingly interwoven with and affected by changes in financial markets (Isakson 2014). Stakes in agricultural commodities, food production, and farmland are increasingly being sliced up and repackaged as financial derivatives that are very attractive to investors because of their expected high returns and the hedging properties that they hold.

As these investments have increased, so has a growing chorus of concern over the social and ecological consequences of these investments. To be sure, the balance sheet has been deeply contested. Some make the case that these investments provide much needed capital for the sector, and that they provide liquidity for commodity markets, assisting in price discovery and calming market volatility (Sanders and Irwin 2010). Others have pointed out the potential for commodity speculation to drive food price volatility, with direct implications for hunger in the world's poorest countries (Ghosh 2010). Critics have also connected financial actors to largescale land acquisitions for biofuel crop production, which has the potential to displace smallholders and drive ecological damage due to land clearing for industrial agricultural operations (McMichael 2010; White et al. 2011; Wise 2012).

Civil society organizations jumped fully into the debate after 2010, arguing for regulatory efforts to curb speculative financial investments in the food system, which they linked to food price volatility, hunger, and environmental degradation (WDM 2011; Foodwatch 2011; Oxfam 2013; FOE 2012; GRAIN 2012). At roughly the same time, a number of international organizations, including the Bank for International Settlements (BIS) and UNCTAD, noted that financial investment in commodities has the potential to influence prices for those commodities, especially in the short term (BIS 2011; UNCTAD 2011a). Similarly, the World Bank has acknowledged that there is widespread neglect of environmental and social norms in international farmland investments (Deininger and Byerlee 2011, p. xxxii). Concerned that "race to the bottom" type practices may contribute to conflict and instability, which ultimately reduce investment incentives, a number of governments and international organizations have promoted precautions 
in order to ensure that these investments are not undertaken in ways that can cause social and environmental harm (Deininger and Byerlee 2011; World Bank and UNCTAD 2014).

\section{The rise of responsible investment initiatives for agriculture and land}

The idea of establishing voluntary principles and codes of conduct to govern agricultural investments emerged within a broader context of voluntary measures for responsible investment, which have been promoted by both governments and business in recent decades. The rise of neoliberal, market-oriented economic policies in the 1980s provided the backdrop for the growing popularity of voluntary initiatives aimed at encouraging private companies and investors to operate sustainably. These initiatives became a prominent governance approach following the Rio Earth Summit in 1992 (see Auld et al. 2008; Utting and Clapp 2008) and were based on the idea that voluntary responsible behavior was in the financial interest of firms because sustainability affects their bottom line over the long term (Schmidheiny 1992). Firms also had an interest in supporting these initiatives because they might serve to pre-empt or weaken future regulation (Lyon and Maxwell 1999).

Some voluntary initiatives were spearheaded by industry, while others have been helped along by international organizations such as the United Nations and Organization for Economic Cooperation and Development (OECD) (Clapp 2005). They include general voluntary principles on corporate practice such as the UN Global Compact, the OECD's Guidelines on Multinational Enterprises, and the International Organization for Standardization's environmental management guidelines ISO 14000 (Fritsch 2008). They also encompass industry-specific certification programs, such as Responsible Care for the chemical industry and the Mining Minerals and Sustainable Development initiative to promote sustainable mining. The Global Reporting Initiative (GRI) establishes standardized templates that firms can voluntarily follow for their corporate social responsibility (CSR) reporting. Disclosure schemes such as the Carbon Disclosure Project (CDP) and the Extractive Industry Transparency Initiative (EITI) rely on transparent reporting and release of information as a means by which to encourage firms to act

responsibly (Clapp and Meckling 2013). Voluntary certification programs have also emerged to 
govern global commodity chains for products ranging from timber, to fisheries, to agricultural goods (Auld 2014).

Among the suite of voluntary initiatives that have emerged in recent years are measures designed specifically to promote responsible private sector financial investment. These finance-specific initiatives in theory encompass all financial investments, including those linked to agriculture and land. The United Nations Environment Program launched its Finance Initiative (UNEP FI) in 1992 to provide a general set of guidelines on sustainable finance with a series of statements that banks and other private financial institutions are asked to sign onto (Clapp and Dauvergne 2011). Other initiatives include the Equator Principles, launched in 2003, which establish social and environmental benchmarks to be used by private financial institutions for assessing project finance in developing countries. The Equator Principles encourage private banks to provide financing only for socially and environmentally sustainable projects in developing countries (Wright 2012). In 2006, the Principles for Responsible Investment were established on the initiative of UNEP FI and the UN Global Compact. These principles are aimed at institutional investors, and encourage them to incorporate environmental, social, and governance (ESG) concerns into their investment analysis and decision-making (Gond and Piani 2012; Sievanen et al. 2013).

Voluntary initiatives aim to convince firms and investors that it is in their own best interest to act responsibly with respect to environmental and social issues. They stress that ESG issues should be incorporated into the business models of firms because they have "material” significance. That is, at the end of the day these issues affect a firm's financial bottom line. Thus, firms are encouraged to sign onto these initiatives not just to “do the right thing” ethically, but also because it matters for their own profitability and returns (Schmidheiny 1992; Carroll and Shabana 2010). Financial investors have the potential to act as a lever to encourage more sustainable behavior by firms seeking to raise capital in financial markets by pressuring them to incorporate ESG issues into their business models, which in turn should result in higher returns from their investments (Kell 2009). Because they manage massive sums of money, institutional investors can potentially have a significant influence on the practices of the firms in which they invest. Large institutional investors, pension funds in particular, have a strong interest in 
participating in voluntary measures for responsible investment because their members are concerned about how their retirement contributions are managed (Gond and Piani 2012). If there is both ethical and material reason to shift investments toward responsible firms, institutional investors are more likely to come on board (Kell 2009, p.8).

The promotional materials of these initiatives make direct links between social and environmental sustainability issues and the material performance of the investments. The UN PRI website, for example, stresses:

Mounting evidence of the financial materiality of ESG issues, alongside growing demands from regulators, clients and beneficiaries for more sustainable approaches to investment, are among the key drivers behind the adoption of responsible investment practices worldwide (UNPRI 2015).

In the agricultural sector, the prevalent discourse for responsibility is characterized by an appeal to institutional investors' long-term outlooks to ensure the ecological and social sustainability of their agricultural investments and the benefits that flow from them. Pension funds, for example, are typically characterized as having longer time horizons than other investors, with more passive investment strategies that seek investment vehicles that require little active maintenance. Advocates of responsible investment stress the importance of these investors in ensuring that farmland investments, for example, are sustainably managed over the long term, particularly because land is an illiquid asset that institutional investors will likely hold for some time (Scott 2013).

A range of initiatives promoting responsible agricultural investment emerged following the 2007-08 food crisis, when the potential for negative impacts from both commodity and land investments became increasingly evident (See Table 1). Although the precise impact of these investments is contested, support has grown for measures to ensure that the benefits of foreign investment in agriculture outweigh any potential costs (Hallam 2011). As public concern grew over land grabbing in the wake of the food price spikes, the Group of Eight (G8) noted in the communiqué from its L’Aquila Summit that it was committed to supporting work on establishing 
a set of principles and best practices to guide agricultural investment (G8 2009; Stephens 2013; Margulis and Porter 2013). The financial industry also endorsed the idea of voluntary measures, which emerged not surprisingly just as the United States and European Union began to work on strengthening financial regulatory measures to curb problems associated with speculation on commodity derivatives markets (Clapp and Helleiner 2012).

One of the first responses to the G8's call was an international roundtable meeting co-hosted by Japan, the World Bank, FAO, the International Fund for Agricultural Development (IFAD), and UNCTAD in September 2009, which brought together 13 organizations and representatives from 31 governments (Japan et al. 2009).This meeting sought to spearhead the development of a set of principles to guide agricultural investment that would “create a 'win-win-win' situation” to promote responsible investment in agriculture that would benefit countries, local communities, and investors (Japan et al. 2009, p.2). The meeting's participants expressed general support for ongoing work by the World Bank, FAO, IFAD, and UNCTAD to further develop these areas into a set of non-legally binding principles. In practice, the World Bank took the lead in this process (Margulis and Porter 2013, p.74).

The resulting document, The Principles for Responsible Agricultural Investment that Respects Rights, Livelihoods and Resources (PRAI), was unveiled in early 2010 (FAO et al. 2010). The PRAI outlines seven key areas to guide investment, including: 1) recognition and respect for existing rights over land and natural resources; 2) ensuring that investments support food security; 3) requiring transparency and good governance in land acquisitions; 4) consultation with and participation of those affected by agricultural investments; 5) ensuring economic viability; 6) promotion of positive social impacts of investments; and 7) encourage environmental sustainability. The G8 and G20 subsequently endorsed the PRAI, and it is acknowledged in the G8's New Alliance for Food Security and Nutrition (Stephens 2013; G8 2012). The PRAI are broad in their application, geared toward guiding any and all investmentpublic, private, foreign, and domestic —including investments from private equity firms, agrifood companies, biofuel firms, financial institutions, sovereign wealth funds, and individual entrepreneurs (FAO et al. 2010). The PRAI are now being field tested for feasibility in some 4550 investments that were already in place across Africa and Southeast Asia (FAO website; 
UNCTAD website; GRAIN 2012; World Bank and UNCTAD 2014).

Separately, another initiative aimed at ensuring responsible investment with a specific focus on land was negotiated at roughly the same time, although discussions on this initiative predate the PRAI. The final declaration of an FAO sponsored International Conference on Agrarian Reform and Rural Development held in 2006 highlighted the importance of establishing guidelines on tenure issues. The process of establishing formal guidelines was launched by the FAO in 2009 (Seufert 2013). The result of this process was the Voluntary Guidelines on the Responsible Governance of Tenure of Land, Fisheries and Forests in the Context of National Food Security (FAO 2012). The Voluntary Guidelines are specifically geared towards protecting land and resource tenure rights in cases of investment in land, fisheries, and forests, and call for the protection of customary land rights for indigenous peoples and smallholders, as well as safeguards to protect the environment. They are focused on ensuring national governments protect those tenure rights and that all stakeholders, including private investors, respect those rights (FAO 2012). The Voluntary Guidelines were developed in a broadly consultative and inclusive process, coordinated by the FAO and involving regional consultations and negotiations at the Committee on World Food Security (CFS), including private sector and civil society participation (McKeon 2013). As such, the Guidelines are widely seen to carry more legitimacy than the PRAI (Margulis and Porter 2013).

As the PRAI and Voluntary Guidelines were being discussed in tandem, including at the Committee on World Food Security in the 2009-12 period, tensions emerged about the two very different processes behind them (McKeon 2013, p.110). Many civil society participants at the CFS refused to formally endorse the PRAI because of its lack of a consultative process and instead preferred to focus efforts on the Voluntary Guidelines (McKeon 2013). Recognizing the need for guidelines that went beyond land tenure and encompassed broader aspects of agricultural investment, and unhappy with the PRAI to serve this purpose, the CFS agreed to develop yet another set of responsible agricultural investment guidelines under a more inclusive process (Stephens 2013, p.190). Consultations on the new initiative, which came to be known as The Principles for Responsible Investment in Agriculture and Food Systems, began in 2012, once the Voluntary Guidelines were finalized and formally adopted by the CFS. The PRIAFS goes 
beyond the PRAI in that it does more to recognize the role of small farmers as investors alongside corporate and financial investors, it places more emphasis on food security and the right to food, and it seeks to bring in more explicit accountability measures for investors (FAO 2014).

At the same time that the UN and other international organizations were seeking to develop guidelines and principles for responsible agricultural investment, initiatives also came forward from other quarters, including private investors themselves. In 2011, a group of signatories to the PRI launched their own voluntary measure, the Principles for Responsible Investment in Farmland (also referred to as the Farmland Principles) that list five key principles (PRI website). The aim of the Farmland Principles is to provide guidance to large-scale institutional investors, such as pension funds, on how to invest responsibly in farmland, including respect for environmental sustainability, human and labor rights, land and resource rights, ethical business standards, and transparency. These principles did not come formally out of the PRI, but rather were independently agreed to by several institutional investors themselves. A group of eight investment funds including TIAA-CREF (a US teachers' pension fund), AP2 (a Swedish government pension scheme), APB (a Dutch government pension scheme), among other investment funds, were the initial signatories. Together, these funds held US\$1.3 trillion in assets at the time that they established these principles. Currently, 16 large institutional investors have signed onto the Farmland Principles. TIAA-CREF is among the largest institutional owners of farmland (with US $\$ 2.5$ billion in farmland assets), and has taken a lead in promoting the Farmland Principles, advertising them prominently through its website and in separate reports on its own investments in farmland (TIAA-CREF 2012).

Additional guides have also been published that seek to provide advice to investors on how to responsibly invest in commodities and farmland. The Responsible Investor's Guide to Commodities, published in 2011, is a joint initiative of the Global Compact, the PRI, the Swiss government, and OnValues — a private consulting firm (Knoepfel and Imbert 2011a). The guide maps out best practices for institutional investors seeking returns from investments in commodity derivatives, physical commodities, and farmland, as well as debt and equity in agricultural commodity producing firms. Its recommendations feature transparency and the establishment 
and maintenance of ESG standards along commodity chains. It acknowledges that negative social and environmental externalities associated with financial investment are possible, and warns that the lack of responsible investment to avoid those costs could "ultimately harm investors' 'license to invest' in those markets” (Knoepfel and Imbert 2011a, p.6). Taking a harder line on the issue, the Interfaith Center on Corporate Responsibility (ICCR) published Guidelines for Responsible Investing in Food Commodities in 2012 (ICCR 2012). Its recommendations for institutional investors are summarized on one page. Institutional investors that are not already investing in commodities are advised not to enter into investments in this asset class, and are advised especially to avoid direct investment in commodities and commodity derivatives, commodity index funds, and exchange-traded funds. For those already in this asset class, recommendations further emphasize transparency, the promotion of ESG standards, advocacy for improved global regulation of commodity trading, and seeking out investments that explicitly provide support for smallholders and that have environmental benefits (ICCR 2012).

\section{Familiar pitfalls of voluntary initiatives: Prospects for agricultural investment}

The broad array of responsible investment initiatives for agricultural commodities and farmland is remarkable in that it represents a major effort from a number of quarters to encourage more responsible agricultural investment from private financial and other investors. Despite the attractiveness of the material rationale for investing responsibly, the academic literature on voluntary measures finds significant weaknesses that compromise their ability to change the environmental and social behavior of firms in practice (Vogel 2010; Clapp and Thistlethwaite 2012). Voluntary corporate sustainability measures tend to share some common pitfalls, many of which reinforce one another, and which must be considered when assessing the likely success or failure of responsible investment initiatives for agriculture. Four key shortcomings stand out in particular: generally weak requirements, low participation rates, uneven application of the business case, and the proliferation of competing initiatives. Each of these is discussed below in relation to agricultural investments.

Weak requirements 
The requirements of voluntary initiatives vary in their level of stringency, depending on the type of initiative under consideration (Auld et al. 2008). Broad sets of voluntary principles, such as the PRI and the Global Compact, are very vague and weak in terms of what they ask for, as well as with respect to implementation and enforcement (Fritsch 2008). As a result, they are largely symbolic, aspirational goals, not legally binding in any way. The terms of engagement are also ambiguous. The UN PRI, for example, asks members to commit to its principles "where consistent with" their fiduciary responsibilities. In other words, investors need only follow the guidance when it does not harm their bottom line.

The responsible agricultural investment initiatives thus far have been broad in scope, without concrete requirements for those that endorse them. The PRAI consists of 7 general principles and does not have any reporting requirements or enforcement mechanisms (UNCTAD website). A World Bank-UNCTAD report on the application of the PRAI in 39 investments noted, for example, that transparency and disclosure were particularly weak (World Bank and UNCTAD 2014, p.11). Similarly, the Farmland Principles are also simply a list of 5 principles with no real enforcement mechanism for signatories, although the fifth principle does call for public reporting on their implementation (PRI website). The PRIAFS, while more detailed than the PRAI in its outline of what constitutes responsibility, does not incorporate its own mechanism for ensuring accountability. Rather, it calls for stakeholders to conduct assessments of potential impact and to take remedial action in cases of negative impacts or non-compliance with national laws (FAO 2014).

Low participation rates

The vagueness of general sets of principles can help to attract signatories, especially if there are potential gains such as the weakening of future regulation and a boost in firms' reputation for joining. In relative terms, however, voluntary responsibility initiatives tend to have low rates of participation. The PRI for example, claims to cover $15 \%$ of the institutional investment market, amounting to some $\$ 34$ trillion in assets, but in practice, less than 5\% of that money is invested in firms with good ESG ratings (Krosinsky 2013). One recent estimate indicates that sustainably invested funds represent only $1 \%$ of all assets managed globally, a very tiny slice (Krosinsky 
2013). Similarly, although the Global Compact has some 12,000 members, which sounds impressive, it is only a small portion of global firms considering that in 2010 there were over 100,000 parent firms of TNCs and nearly 900,000 foreign affiliates (UNCTAD 2011b, tab 34). The firms that do sign on to these broad initiatives may be leaders in their sectors, but many more firms are simply not participants. The Equator Principles appear to enjoy somewhat higher participation rates, although with some caveats. Seventy-nine international private lending institutions have signed on to the Principles, and the initiative claims that this accounts for some 70 percent of project financing debt in emerging countries (Equator Principles website). According to one estimate, however, 90 percent of the lending of the signatory banks falls outside of the scope of the Equator Principles (Wright 2012).

The responsible agricultural investment initiatives are also likely to have weak participation rates. The PRAI, the Voluntary Guidelines, and the PRIAFS are guidance frameworks for stakeholders, and because they are not collecting signatories among private sector investors, it is difficult to know for sure how many investors are following them. The PRI Farmland has 16 signatories, which are made up primarily of pension funds - a small slice of the 1200 investment funds that are PRI members. Recent private sector stakeholder meetings on responsible investment in agriculture indicate that most big players in agricultural investment are not yet at the table (Knoepfel and Imbert. 2011b, p.19).

Uneven application of the "business case"

The "business case" for implementing voluntary corporate responsibility initiatives is weak in many cases, which helps to explain the low rates of participation. The effort to sign onto a voluntary initiative has to be worth it to the firm (Lydenberg 2013). Usually this is the case when a firm seeks to protect its brand reputation or bottom line (Vogel 2005). Although these factors may apply to some firms who make environmental and social responsibility a key feature of their business model and products, or in cases of high profile firms whose brand reputations are at risk if they do not take on corporate responsibility activities, these are only a small subset of all firms (Vogel 2005). Firms may undertake cost-saving measures in any case and consider these CSR initiatives, but going further than that has proven to be a challenge for many firms. This 
constraint has been apparent in the case of climate change initiatives, where energy efficiency and waste minimization measures are typically undertaken by firms because they result in immediate cost savings, whereas more difficult and costly measures, such as biodiversity conservation, are typically left unaddressed (Clapp and Thistlethwaite 2012).

Further, there is only mixed evidence on whether incorporation of ESG issues into firm management and financial investment actually results in superior financial performance of either firms or their investors. Most studies indicate that it is a wash: no clear trend either way. As Vogel notes, "For virtually all firms, their CSR performance and reputations remain largely irrelevant to their financial performance: they neither improve it nor detract from it” (Vogel 2010, p.82). Indeed, only 9\% of investments of PRI signatories actually perform well on ESG indicators, indicating that there is little financial benefit for doing so (Sullivan 2012).

The weak business case for signing on to voluntary initiatives already seems to be the case with agricultural investments. In cases where adherence to an initiative is important for "brand reputation,” there has been more involvement. Large transnational agrifood processing companies with widespread name brand recognition, such as Nestlé and Unilever, for example, have taken the lead in the certification initiatives for sustainable palm oil, which is a key ingredient in many of their products (WWF 2012). But for less visible firms and financial actors that are not as concerned about their brand reputation, there is less incentive to pledge responsibility via voluntary initiatives, as is discussed more fully below.

Confusing array of competing initiatives

There is a proliferation of initiatives servicing the same or similar needs that could lead to a level of both complexity and confusion. Multiple voluntary measures seeking similar outcomes allows firms and investors to pick and choose which set of guidelines they wish to follow (Utting and Clapp 2008). In the case of forestry, for example, after the Forest Stewardship Council brought forward its certification initiative, which was based on multiple stakeholder input and strict certification requirements, other forest certification schemes emerged that were industry-led and had less stringent requirements (Cashore 2002). Consumers looking for sustainably harvested 
timber products may not realize that there are important differences in what the different certification logos actually require of producers, enabling those following lesser standards to still protect their brand reputation. This crowded landscape, in effect, puts further pressure on the various responsibility initiatives to not be too rigorous in their requirements for fear of driving away participants.

There has also been a proliferation of initiatives in the agricultural investment space. The guidelines and principles that have emerged cover overlapping themes, and proponents claim that each applies to multiple stakeholders. But the landscape of these initiatives is already confusing. With respect to farmland investments, for example, confusion over the differences between the PRAI, Voluntary Guidelines on Tenure, the PRIAFS, and PRI Farmland Principles has already led to questions regarding the target, coverage, and scope of each set of principles (Margulis and Porter 2013).

In sum, there are strong parallels between the more general environmental and social responsibility initiatives geared to firms, and those emerging in the realm of agricultural investment geared to investors. Despite their best intentions, to date responsible investment initiatives have suffered from weaknesses that limit their transformative potential. In many ways these weaknesses appear to already be applicable to the new responsible investment initiatives in agriculture, indicating that reliance on these sorts of initiatives alone is likely to be insufficient to transform the nature of financial investments in the sector.

\section{Private financial investment complicates responsibility efforts}

Beyond these general pitfalls of voluntary sustainability initiatives for business, there are several unique features of financial investments in agricultural commodities and farmland that make them difficult to govern effectively with voluntary mechanisms. Because the markets are highly complex and the actors are so diverse, it is especially difficult to draw the lines of cause and effect, linking investors to responsibility for outcomes on the ground. If responsibility cannot be attributed to specific investors or even groups of investors, then those investors are unlikely to be convinced to change their investment practices voluntarily. 
Voluntary responsibility efforts have focused on changing the behavior of firms - either directly through corporate social responsibility, or indirectly via investor or bank pressure. The Global Compact targets firms directly; the PRI targets investors' engagement with firms; and the Equator Principles target banks’ financing of firms’ projects. Financial investment in agriculture does not always fall into the category of straightforward investment in firms, but also includes investment in agricultural-based derivatives products which themselves can have an impact on market fluctuations, in turn affecting food prices and access to food. In other words, ensuring investment in agriculture is responsible is not just about altering the behavior of firms engaged in agriculture, but also the behavior of financial investors and financial institutions that trade derivatives products. Looking more closely at the role of financial actors in international agricultural investment reveals several interrelated features of agricultural finance and investment that make the effort to ensure responsibility especially challenging.

Complexity of agriculture-based financial investments

First, the role played by financial investors in agriculture complicates the picture enormously because money is fungible-meaning that because money is mutually interchangeable with other money-it is difficult to determine whose money is responsible for which activities. Further, the agricultural derivatives that financial investors buy into are highly complex, as are the linkages between various financial investors. Bulk commodities that are traded on futures markets are also fungible - that is, a bushel of corn is a bushel of corn and separating out sustainably produced corn from other corn in these markets is nearly impossible at this time. These features make tracing financial investment in abstract derivatives to certain actors, and to real world outcomes, extremely difficult.

A large portion of the investment in the agricultural sector is in financial derivatives products, including index funds that track prices of a bundle containing different types of investments (Knoepfel and Imbert 2011a). As noted above, some commodity index funds bundle agricultural commodities with non-agricultural commodities, while others focus on a range of agricultural investments including commodity futures, firm shares, and farmland. Index investments are 
purely financial in nature, and as such, it becomes much less clear whose money is responsible for which outcomes. Financial institutions that offer agricultural index products to investors often make direct investment in commodity futures markets, another form of financial derivative, in order to hedge their risks associated with selling index products. Both kinds of investments can influence overall commodity price trends, which in turn influences further investment, both financial and in physical commodities and land. Holding financial investors responsible for outcomes in this context is challenging, to say the least.

The complexity of financial derivatives is compounded by the myriad relations different investor groups have to one another, which also makes it difficult to point at any one investor group as being responsible for a particular investment trend. As noted above, a range of actors, including sovereign wealth funds, pension funds, hedge funds, private equity funds, investment banks, and agribusiness firms are all involved in financial investment in various types of agricultural-linked investment products. Tracking the activity of institutional investors, as noted in an FAO working paper on private foreign investment in agriculture, is difficult, even for industry analysts. Hedge funds, for example, are not required to publicly disclose their investments (McNellis 2009, p.3). Further, these investor groups are often cross-investing in one another. As McNellis notes: "For example, a sovereign wealth fund could be investing in a private equity fund which in turn invests in a specialized hedge fund that is buying agricultural land while at the same time investing in the various commodity markets” (McNellis 2009, p.2). This complexity makes it extremely difficult to tease out which investors are driving investments, and which should be held responsible for outcomes.

Not only are the instruments and investors difficult to disentangle from one another, but their connection to outcomes is also fuzzy. Consider a case where investors are putting large sums of money into commodity futures and index funds, and these investments in turn contribute to volatility of food prices, which in turn drives investment by unrelated firms in large-scale agricultural and land investments that have social and ecological consequences, such as forest clearing and smallholder displacement from land. Should the financial investors who put their money in index funds be held responsible, when their own investments are not tied to concrete investments in any specific location? The lack of a direct tangible link between the financial 
investments and the outcomes on the ground complicates the issue. I have referred elsewhere to this problem as one of financial "distancing” in the agrifood value chain (Clapp 2014). The complexity and abstraction of financial investment derivatives in the agricultural sector only compound this distance and make it extremely challenging to draw clear lines of responsibility from investor to outcomes.

The lack of clear lines regarding the responsibility of financial actors also reduces their incentives to participate in voluntary measures. A consultant for the Swiss Government, the UN PRI, and the Global Compact interviewed investors about their role in commodities investments, and noted that although most investors agreed that growing investments in commodities could lead to greater price volatility, "They do not see themselves as being primary actors in futures markets and question the notion of responsibility for those markets” (Knoepfel 2011, p.25). Investors view investment by pension funds in commodity futures, for example, as unproblematic. Instead, investors saw responsibility for environmental, social, and corporate governance issues as being more closely tied to "investments in physical commodities, real assets and equity of extractive/resource intensive companies” (Knoepfel 2011, p.25).

Short-term - long-term mismatch

Second, the mismatch between long-term needs of sustainable agriculture and the short-term nature of global finance tends to weaken the business case for responsibility even further. Financial markets have been seen as a problem for the environment because they prioritize returns in the short term, which often goes against longer-term environmental aims (Helleiner 2011). Some have argued because institutional investors, in particular pension funds, have a longer-term outlook, they have a stronger chance of seeing benefits in sustainable investments (e.g. MacLeod and Park 2011). Large prominent public pension funds, for example, have been leading signatories of the PRI Farmland, which may be linked to their high visibility among their members. Harmes (2011), however, argues that the business case for environmentally sustainable financial investment, even among institutional investors such as pension funds, is weak at best. He argues that most pension funds hire external managers who are evaluated on short-term performance criteria, which in practice results in decisions that prioritize immediate returns over 
longer-term stewardship. Moreover, the passive nature of institutional investors makes it difficult for them to switch investments once they are made.

Lack of branding for certain financial actors

Third, many financial actors lack a public brand image and as such are not necessarily swayed by arguments that investing sustainably is good for their bottom line. As de Man (2013) points out, only a few investor types have a clear business case for responsible agricultural investment. In the case of farmland investors, those that may have some incentive to invest responsibly are those with a high profile public face, such as development finance institutions, agrifood companies that have strong brands and high visibility, publicly held pension funds, and biofuel firms that are seeking to enter publicly regulated markets (de Man 2013, p.17). For these investors, there is a case for ensuring that their investments, particularly in farmland and commodity production, are responsible, largely because external scrutiny may result in a loss of business or reputation. But for other investors, including large agricultural commodity traders and processors of raw materials, sovereign wealth funds, and private equity funds, there is likely no business case because these firms do not have the branding or public profiles of the others. These firms are often operating in ways that are not transparent to the public in any case. As de Man notes, wealthy individuals and pure financial speculators actually have a "business case for opacity” rather than transparency (de Man 2013, p.19).

With financial investments in derivatives such as commodity futures and index products, the business case becomes even less clear because there is only an indirect link to land or production and thus connections to outcomes, as noted above, are less easily discernable. Yet futures and over-the-counter derivative products are the most common way that investors gain exposure to the commodities sector, which is a large component of agricultural investment overall (Knoepfel and Imbert 2011b, p.15). Moreover, fund managers often see greater payoffs when following the herd, which is often driven by high frequency, algorithmic trading (Skypala 2013). Institutional investors often do not understand commodity markets particularly well, further hampering their ability to demand responsibility measures (Knoepfel and Imbert 2011b, p. 18). As Skypala 
(2013) notes, expecting institutional investors to lead the way on responsibility issues is “probably naïve.”

\section{Conclusion}

Increased financial investment in agriculture has changed the agricultural landscape significantly in recent years. Financial actors are increasingly investing in a range of agricultural investment products, including agricultural commodity futures, commodity index funds, agricultural funds, farmland, and commodity production firms. As concerns have mounted over whether this new financial investment is prone to result in negative externalities, voluntary initiatives for responsible agricultural investment have begun to emerge from a number of quarters, led both by international organizations and investors themselves. This paper has made the case that voluntary initiatives for responsible agricultural investment are likely to mirror the weaknesses exhibited by more general responsible investment initiatives. Vague guidance on the specifics, combined with a lack of concrete enforcement mechanisms, make it easy to claim adherence to these initiatives, but difficult to verify that claim. Weak rates of participation, a flimsy business case for most firms and investors, as well as confusion due to multiple initiatives, are likely to result in little change in investment behavior in practice.

In addition to these general lessons from the voluntary initiatives literature, there are further features of financial investment in agriculture that pose additional challenges for voluntary agricultural investment initiatives. The highly complex nature of these derivatives markets makes drawing the lines of cause and effect extremely difficult. But even if such linkages could be drawn clearly, the business case for responsible financial investment is far from clear, as fund managers and large institutional investors typically operate on short-term performance criteria rather than longer-term sustainability goals, and they often lack a brand image that would encourage them to ensure that their investments are responsible.

The various agricultural investment initiatives outlined in this paper do not provide any level of detail that outlines measures to ensure responsibility with respect to financial investment in agricultural derivatives investments, a major category of financial investment in the sector. And 
because these initiatives are not generally monitored or enforced by governments, there is a risk that the new spate of responsible investment initiatives for agriculture will not shift the practice of financial investment in agriculture, although they may serve to preempt or weaken future regulation of this type of investment. If more effective solutions are to be found, it is important that we learn from the past failures of voluntary initiatives and consider the unique features of private finance more centrally in their design.

\section{References}

Auld, G., S. Bernstein, and B. Cashore. 2008. The new corporate social responsibility. Annual Review of Environment and Resources 33: 413-435.

Auld, G. 2014. Constructing private governance: The rise and evolution of forest, coffee, and fisheries certification. New Haven, CT: Yale University Press.

Berkovitz, D. 2009. Position limits and the hedge exemption, brief legislative history. Testimony of General Counsel D.M. Berkovitz, Commodity Futures Trading Commission. http://www.cftc.gov/PressRoom/SpeechesTestimony/berkovitzstatement072809. Accessed 29 April 2015.

Bank for International Settlements (BIS). 2011. $81^{\text {st }}$ Annual Report. Basel: Bank for International Settlements. http://www.bis.org/publ/arpdf/ar2011e.pdf. Accessed 29 April 2015.

Burch, D., and G. Lawrence. 2009. Towards a third food regime: Behind the transformation. Agriculture and Human Values 26(4): 267-279.

Carroll, A.B., and K.M. Shabana. 2010. The business case for corporate social responsibility: A review of concepts, research and practice. International Journal of Management Reviews 12(1): 85-105.

Cashore, B. 2002. Legitimacy and the privatization of environmental governance: How non-state market-driven (NDSM) governance systems gain rule-making authority. Governance 15(4): 503-529.

Clapp, J. 2005. Global environmental governance for corporate responsibility and accountability. Global Environmental Politics 5(3): 23-34.

Clapp, J. 2014. Financialization, distance and global food politics. The Journal of Peasant Studies 41(2): 1-18. 
Clapp, J., and P. Dauvergne. Paths to a green world: The political economy of the global environment. Cambridge, MA: MIT Press.

Clapp, J., and E. Helleiner. 2012. Troubled futures? The global food crisis and the politics of agricultural derivatives regulation. Review of International Political Economy 19(2): 181-207. Clapp, J., and J. Thistlethwaite. 2012. Private voluntary programs in environmental governance: Climate change and the financial sector. In Business and climate policy: Potentials and pitfalls of voluntary programs, ed. K. Ronit, 43-76. UN University Press.

Clapp, J., and J. Meckling. 2013. Business as a global actor. In The handbook of global climate and environment policy, ed. R. Falkner, 286-303. Chichester, UK: Wiley-Blackwell.

Cronon, W. 1991. Nature's metropolis: Chicago and the Great West. New York: W. W. Norton \& Company.

Daniel, S. 2012. Situating private equity capital in the land grab debate. The Journal of Peasant Studies 39(3-4): 703-729.

Deininger, K.W., and D. Byerlee. 2011. Rising global interest in farmland: Can it yield sustainable and equitable benefits? Washington, DC: World Bank Publications.

De Man, R. 2013. The business case for transparent land deals. Paper presented at the Annual World Bank Conference on Land and Poverty. Washington, DC: World Bank. http://www.commercialpressuresonland.org/sites/default/files/de_Man-222_paper.pdf. Accessed 29 April 2015.

De Schutter, O. 2010. Food commodities speculation and food price crises. UN Special Rapporteur on the Right to Food Briefing Note 02 - September. http://www2.ohchr.org/english/issues/food/docs/Briefing_Note_02_September_2010_EN.pdf. Accessed 29 April 2015.

Epstein, G.A. 2005. Introduction: Financialization and the world economy. In Financialization and the world economy, ed. G.A. Epstein, 3-16. Cheltenham: Edward Elgar.

Fairbairn, M. 2014. 'Like gold with yield': Evolving intersections between farmland and finance. The Journal of Peasant Studies 41(5): 777-795.

FAO, IFAD, UNCTAD, and World Bank. 2010. Principles for responsible agricultural investment that respects rights, livelihoods and resource. Discussion Note. http://siteresources.worldbank.org/INTARD/2145741111138388661/22453321/Principles_Extended.pdf. Accessed 29 April 2015. 
FAO. 2012. Voluntary guidelines on the responsible governance of tenure of land, fisheries and forests in the context of national food security. Rome: FAO.

http://www.fao.org/docrep/016/i2801e/i2801e.pdf. Accessed 29 April 2015.

FAO. 2014. Principles for Responsible Investment in Agriculture and Food Systems. Adopted by the Committee on World Food Security. http://www.fao.org/3/a-au866e.pdf. Accessed January 10, 2016.

Foodwatch. 2011. The hunger-makers: How Deutsche Bank, Goldman Sachs and other financial institutions are speculating with food at the expense of the poorest. Berlin: Foodwatch. Friends of the Earth. 2012. Farming money: How European banks and private finance profit from speculation and land grabs. https://www.foeeurope.org/farming-money-Jan2012. Accessed 29 April 2015.

Fritsch, S. 2008. The UN global compact and the global governance of corporate social responsibility: Complex multilateralism for a more human globalisation? Global Society 22(1): $1-26$.

Fuchs, D., R. Meyer-Eppler, and U. Hamenstädt. 2013. Food for thought: The politics of financialization in the agrifood system. Competition \& Change 17(3): 219-233.

Ghosh, J. 2010. The unnatural coupling: Food and global finance. Journal of Agrarian Change 10(1): 72-86.

Gond, J-P., and V. Piani. 2013. Enabling institutional investors' collective action: The role of the principles for responsible investment initiative. Business \& Society 52(1): 64-104.

GRAIN. 2012. Responsible farmland investing? Current efforts to regulate land grabs will make things worse. http://www.grain.org/article/entries/4564-responsible-farmland-investing-currentefforts-to-regulate-land-grabs-will-make-things-worse. Accessed 29 April 2015. Group of Eight (G8). 2009. Responsible leadership for a sustainable future. http://www.g8italia2009.it/static/G8_Allegato/G8_Declaration_08_07_09_final\%2c0.pdf. Accessed 29 April 2015.

Group of 8 (G8). 2012. Fact Sheet: G8 Action on Food Security and Nutrition. https://www.whitehouse.gov/the-press-office/2012/05/18/fact-sheet-g-8-action-food-securityand-nutrition. Accessed 10 January, 2016.

Hallam, D. 2011. International investment in developing country agriculture-issues and challenges. Food Security 3(1): 91-98. 
Harmes, A. 2011. The limits of carbon disclosure: Theorizing the business case for investor environmentalism. Global Environmental Politics 11(2): 98-119.

Helleiner, E. 2011. Introduction: The greening of global financial markets? Global Environmental Politics 11(2): 51-53.

HighQuest Partners, United States. 2010. Private Financial Sector Investment in Farmland and Agricultural Infrastructure. OECD Food, Agriculture and Fisheries Papers, No. 33. OECD Publishing. http://dx.doi.org/.

IATP. (2008). Commodities market speculation: The risk to food security and agriculture. Minneapolis: Institute for Agriculture and Trade Policy.

http://www.iatp.org/files/451_2_104414.pdf. Accessed 29 April 2015.

Interfaith Center on Corporate Responsibility (ICCR). 2012. Guidelines for responsible investment in food commodities.

http://www.iccr.org/sites/default/files/resources_attachments/2012ICCRGuidelinesForInvestingI nFoodCommoditiesFINAL.pdf. Accessed 2 May 2015.

Isakson, S.R. 2014. Food and finance: The financial transformation of agro-food supply chains. The Journal of Peasant Studies 41(2): 1-27.

Japan, UNCTAD, FAO, World Bank, and IFAD. 2009. Promoting responsible international investment in agriculture.

http://www.mofa.go.jp/policy/economy/fishery/agriculture/summary0909.pdf. Accessed 29 April 2015.

Kell, G. 2009. Responsible Investment: Why Should Private Equity Care? International Trade Forum, no. 4 (December): 7-9.

Knoepfel, I. 2011. Responsible investment in commodities: The issues at stake and a potential role for institutional investors. OnValues, Swiss Federal Department of Foreign Affairs, UN Global Compact, and UN PRI. http://www.onvalues.ch/images/publications/11-

01_RI_commodities_Jan2011_v02.pdf. Accessed 29 April 2015.

Knoepfel, I., and D. Imbert. 2011a. The responsible investor's guide to commodities. OnValues, Swiss Federal Department of Foreign Affairs, UN Global Compact, and UN PRI.

http://www.onvalues.ch/images/publications/ri\%20guide\%20to\%20commodities_2011.pdf. Accessed 29 April 2015.

Knoepfel I., and D. Imbert. 2011b. Agri-investing for the long-term: The investment case for responsible investments in agriculture. Conference Report. Geneva: OnValues. 
http://www.onvalues.ch/images/publications/agri-investing_meeting_report_2011.pdf. Accessed 29 April 2015.

Krosinsky, C. 2013. The state of ownership. Network for Sustainable Financial Markets White Paper Series, March. http://www.sustainablefinancialmarkets.net/papers/. Accessed 29 April 2015.

Kugelman, M., and S. Levenstein. 2012. The global farms race: Land grabs, agricultural investment and the scramble for global food security. Washington, DC: Island Press.

Lydenberg, S. 2013. Responsible investors: Who they are, what they want. Journal of Applied Corporate Finance 25(3): 44-49.

Lyon, T.P., and J.W. Maxwell. 1999. Corporate environmental strategies as tools to influence regulation. Business Strategy and the Environment 8(3): 189-196.

MacLeod, M., and J. Park. 2011. Financial activism and global climate change: The rise of investor-driven governance networks. Global Environmental Politics 11(2): 54-74.

Margulis, M.E., and T. Porter. 2013. Governing the global land grab: Multipolarity, ideas, and complexity in transnational governance. Globalizations 10(1): 65-86.

McKeon, N. 2013. 'One does not sell the land upon which the people walk’: Land grabbing, transnational rural social movements, and global governance. Globalizations 10(1): 105-122. McMichael, P. 2010. Agrofuels in the food regime. The Journal of Peasant Studies 37(4): 609629.

McNellis, P.E. 2009. Foreign investment in developing country agriculture-The emerging role of private sector finance. FAO Commodity and Trade Policy Research Working Paper (28). http://www.fao.org/fileadmin/templates/est/INTERNATIONAL-TRADE/FDIs/mcnellis.pdf. Accessed 29 April 2015.

Oxfam France. 2013. Réforme bancaire: Ces banques françaises qui spéculent sur la faim. https://www.oxfamfrance.org/sites/default/files/file_attachments/policy_paper/rapport_oxfam_fr ance_reforme_bancaire_120213.pdf. Accessed 29 April 2015.

Sanders, D.R., and S.H. Irwin. 2010. A speculative bubble in commodity futures prices? Crosssectional evidence. Agricultural Economics 41(1), 25-32.

Schmidheiny, S.1992. Changing course. Cambridge, MA: MIT Press.

Scott, M. 2013. Investors take an interest in farmland. Financial Times. January 22. 
Seufert, P. 2013. The FAO voluntary guidelines on the responsible governance of tenure of land, fisheries and forests. Globalizations 10(1): 181-186.

Sievanen, R., J. Sumelius, K.M. Zahidul Islam, and M. Sell. 2013. From struggle in responsible investment to potential to improve global environmental governance through UN PRI. International Environmental Agreements-Politics Law and Economics 13(2): 197-217. Skypala, P. 2013. Investors must use their powers for good. Financial Times. June 9. Stephens, P. 2013. The principles of responsible agricultural investment. Globalizations 10(1): 187-192.

Sullivan, R. 2012. Managers ‘talk more than walk’ on SRI. Financial Times. April 1. TIAA-CREF. 2012. Responsible investment in farmland: Ethical conduct and responsible stewardship of the environment. https://www.tiaa-cref.org/public/pdf/Farmland-SustainabilityReport.pdf. Accessed 29 April 2015.

UNCTAD. 2001. World investment report. Geneva: UNCTAD.

UNCTAD. 2011a. Price formation in financialized commodity markets: The role of information. http://unctad.org/en/Docs/gds20111_en.pdf. Accessed 29 April 2015.

UNCTAD. 2011b. World investment report. Geneva: UNCTAD. Web table 34. http://unctad.org/Sections/dite_dir/docs/WIR11_web\%20tab\%2034.pdf. Accessed 29 April 2015.

UNCTAD. 2012. World investment report. Geneva: UNCTAD.

UNPRI. 2015. “Introducing responsible investment.” http://www.unpri.org/introducingresponsible-investment/ (accessed 1 October, 2015).

Utting, P., and J. Clapp, eds. 2008. Corporate accountability and sustainable development. Delhi: Oxford University Press.

Vogel, D. 2010. The private regulation of global corporate conduct: Achievements and limitations. Business \& Society 49(1): 68-87.

Vogel, D.J. 2005. Is there a market for virtue? The business case for corporate social responsibility. California Management Review 47(4): 19-45.

White, B., S.M. Borras Jr., R. Hall, I. Scoones, and W. Wolford. 2012. The new enclosures:

Critical perspectives on corporate land deals. The Journal of Peasant Studies 39(3-4): 619-647. 
Wise, T. 2012. The cost to developing countries of US corn ethanol expansion. Global Development and Environment Institute Working Paper No. 12-2.

http://www.ase.tufts.edu/gdae/Pubs/wp/12-02WiseGlobalBiofuels.pdf. Accessed 29 April 2015. World Bank and UNCTAD. 2014. The practice of responsible investment principles in largerscale agricultural investments: Implications for corporate performance and impact on local communities. World Bank Report No. 86175-GLB.

World Development Movement. 2011. Stop gambling on food \& hunger: Call for immediate action on financial speculation on food commodities.

http://www.globaljustice.org.uk/sites/default/files/files/resources/food_spec_statement_02.2011_ 0.pdf. Accessed 29 April 2015.

Worthy, M. 2011. Broken markets: How financial market regulation can help prevent another global food crisis. World Development Movement.

http://www.globaljustice.org.uk/sites/default/files/files/resources/broken-markets.pdf. Accessed 29 April 2015.

Wright, C. 2012. Global banks, the environment, and human rights: The impact of the Equator Principles on lending policies and practices. Global Environmental Politics 12(1): 56-77. WWF. 2012. The 2050 criteria: Guide to responsible investment in agricultural, forest and seafood commodities. http://awsassets.panda.org/downloads/the_2050_critera_report.pdf. Accessed 29 April 2015. 